\title{
PENDIDIKAN SEKS DALAM PERSPEKTIF ISLAM (ANALISIS TEKS AYAT ALQURAN)
}

\author{
Rini Rahman \\ Universitas Negeri Padang, rinirabman@fis.unp.ac.id \\ Indah Muliati \\ Universitas Negeri Padang, indabmuliati@fis.unp.ac.id
}

\begin{abstract}
Sex education in Islam is not new. Because when speaking aqidah, worship and morality, there is sex education included in thaharah discussions. Sex education in Islamic perspectives here is an effort to provide knowledge about biological changes in humans, reproductive organs and their functions and how to maintain the reproductive organs they have by instilling moral, ethical and Islamic religious commitments so that they do not occured abuse of reproductive organs. The purpose of sex education in Islam is to maintain the safety and honor and purity of the generation of Islam in the midst of society. Sex education is also given to bumanity, so that they do not fall into the abyss of mischief, namely adultery.
\end{abstract}

Keywords: Pendidikan, seksual, perspektif Islam

\begin{abstract}
Abstrak
Pendidikan seks dalam Islam bukanlab hal yang baru. Karena ketika berbicara aqidah, ibadah dan akblak maka ada pendidikan seks termasuk dalam diskusi thaharah. Pendidikan seks dalam pespektif Islam disini adalah suatu upaya untuk memberikan pengetabuan tentang perubahan-perubahan biologis pada manusia, alat-alat reproduksi dan fungsinya serta bagaimana cara untuk menjaga alat-alat reproduksi yang dimilikinya tersebut dengan menanamkan moral, etika serta komitmen agama Islam agar tidak terjadi penyalahgunaan organ reproduksi tersebut.Tujuan pendidikan seks dalam Islam adalah untuk menjaga keselamatan dan kehormatan serta kemurnian generasi Islam di tengah-tengah mayarakat. Pendidikan seks juga diberikan kepada umat manusia, agar mereka tidak terperosok ke dalam jurang kenistaan, yakni perzinahan.
\end{abstract}

Kata kunci: Pendidikan, seksual, perspektif Islam

\section{PENDAHULUAN}

Beberapa waktu ini isu tentang perilaku seks menyimpang menguak ke permukaan menjadi pembahasan dan perdebatan panjang di berbagai media, ormas, dan lembaga pemerintah. Salah satu penyebab terjadinya perilaku seks yang menyimpang adalah karena ketidakpahaman masyarakat tentang pendidikan seks.

Pendidikan seks seharusnya menjadi bentuk kepedulian orang tua terhadap masa depan anak dalam menjaga apa yang telah menjadi kehormatannya, terlebih bagi seorang perempuan. Pendidikan seks menjadi penting mengingat banyaknya kasus-kasus yang terjadi mengenai tindak kekerasan seksual terhadap anak dan remaja. Tetapi yang terjadi di lapangan justru orang tua bersikap apatis dan tidak berperan aktif untuk memberikan pendidikan seks sejak usia dini kepada anaknya. Mereka beranggapan bahwa pendidikan seks akan diperoleh anak seiring berjalannya usia ketika ia sudah dewasa nanti. Mereka seolah menyerahkan pendidikan seks kepada pihak sekolah sebagai sumber ilmu bagi anaknya. Padahal pendidikan seks sendiri belum diterapkan secara khusus dalam kurikulum sekolah. 
Kurangnya pengetahuan orang tua terhadap kebutuhan anaknya sendiri dalam mengahadapi tuntutan zaman yang semakin berkiblat ke arah barat menjadi faktor utama belum tersampaikannya pendidikan seks sejak usia dini di lingkup keluarga.

Di dalam Islam dorongan seks tidak dianggap tabu atau kotor. ${ }^{1}$ Seks adalah kebutuhan asasi yang tidak dapat dipisahkan dalam kehidupan manusia. Hal ini menunjukkan bahwa kebutuhan seksual pada diri manusia merupakan kebutuhan dasar. ${ }^{2}$

Pendidikan seks adalah sebuah pengetahuan yanng sangat dibutuhkan oleh setiap orang, para remaja laki-laki dan wanita, orang dewasa, setiap ayah dan ibu sebagai orang tua yang memiliki anak, apalagi menginjak usia remaja. Bagi anak - anak yang menginjak usia remaja biasanya akan mencari - cari dan bertanya tentang seks dan perilakunya karena mereka sangat membutuhkannya, sebelum mereka bertanya dan mencari $\mathrm{p}$ ada orang dan tempat yang tidak tepat yang menyebabkan rusaknya pemahaman mereka tentang seks dan rusaknya ahklak mereka karena ketidak pahaman maka disinilah dibutuhkan sesegera mungkin peran seorang ayah dan ibu untuk mengenalkan mereka

Pada pendidikan seks yang syar'i yaitu pola pendidikan seks yang sesuai dengan nilainilai ke Islaman. Setiap orang tua sebaiknya telah mempersiapkan sejak awal tentang pendidikan ini dalam kehidupan keluarga saling bekerjasama, bahu membahu untuk mendidik putra putrinya sehingga muncul pemahaman dan pengamalan yang tepat sesuai dengan pendidikan Islam. Sedangkan keterlambatan dalam memahamkan mereka akan menyebabkan munculnya kaum muda mudi yang salah persepsi tentang

${ }^{1}$ Abdullah Nashih Ulwan, dan Hasan Hathout. Pendidikan Seks, (Bandung: Remaja Rosydakarya, 1992), h. 129

2 Ayip Syafrudin, Islam dan Pendidikan Seks Anak, (Solo: Pustaka Manfiq,1991), h. 11 pendidikan seks sehingga memunculkan perilaku seksual yang menyimpang dari norma kehidupan yang benar.

Seiring dengan menipisnya pendidikan keislaman di Indonesia, seiring pula meningkatnya angka seks bebas. Hal ini wajar saja karena norma mengenai seksualitas yang diajarkan oleh Islam semakin lama-semakin menipis sehingga kesadaran masyarakat untuk melakukan kontrol diri menjadi berkurang. Padahal Islam sangat banyak sekali memberikan ajaran-ajaran moral mengenai seksualitas.

\section{PENGERTIAN PENDIDIKAN SEKS}

Pendidikan adalah proses pembantu dalam membangun dan mengembangkan segala potensi peserta didik sebagai akibat dari pergumulan antara individu dan lingkungannya yang berlangsung semenjak kecil hingga hembusan nafas terakhir. ${ }^{3}$ Pendidikan adalah bimbingan, pimpinan secara sadar yang sistematis oleh pendidik terhadap perkembangan jasmani dan rohani peserta didik melalui kegiatan bimbingan, pengajaran, dan atau latihan bagi peranannya di masa yang akan datang. Dimana, tujuan dan tugas seorang pendidik adalah membimbing dan membina peserta didik dalam mengaktualisasikan diri pribadinya, sesuai dengan nilai-nilai yang berlaku. ${ }^{4}$

Menurut Dr. Abdullah Nashih Ulwan, pendidikan seks adalah upaya pengajaran, penyadaran, dan penerangan tentang masalah-masalah seksual yang diberikan kepada anak sejak, sehingga ketika anak telah tumbuh menjadi seorang pemuda dan dapat memahami urusan-urusan kehidupan, ia telah mengetahui masalahmasalah yang diharamkan dan dihalalkan. Lebih jauh lagi, ia bahkan mampu menerapkan

\footnotetext{
${ }^{3}$ Hasan Langulung, Asas-asas Pendidikan Islam, (Jakarta: Pustaka al-Husna, 1988), h.3-4

4 Rini Rahman, Nilai-nilai Pendidikan dalam Karya Sastra Hamka dan Transformasinya dalam Pembelajaran di Sekolah, (Jakarta: Prasasti, 2015), h. 15
} 
tingkah laku islami sebagai akhlak, dan kebiasaan hidup, serta tidak diperbudak syahwat dan dan tenggelam dalam gaya hidup hedonis. ${ }^{5}$

Berdasarkan penngertian pendidikan seks oleh Abdullah Nashih Ulwan di atas, dapat dipahami bahwa bahwa esensi pendidikan seksual adalah upaya dalam mentransfer pengetahuan dan nilai pada anak tentang fisiologi dan fungsi fisik terkait dengan jenis kelamin (sex) laki-laki dan perempuan. Dengan pengetahuan yang dimiliki diharapkan dapat membuat anak tumbuh menjadi remaja yang mengetahui mana yang halal mana yang haram terkait dengan masalah seksualnya. sehingga, diharapkan dirinya mampu menerapkan perilaku islami sebagai akhlaq kesehariannya dan menjauhi hubungan seksual yang abnormal / terlarang.

Pendidikan seks dapat diartikan sebagai penerangan tentang anatomi, phisiologi seks manusia dan bahaya penyakit kelamin. $^{6}$

Menurut Sarlito dalam buku Psikologi Remaja, secara umum pendidikan seksual adalah suatu informasi mengenai persoalan seksualitas manusia yang jelas dan benar, yang meliputi proses terjadinya pembuahan, kehamilan, sampai kelahiran, tingkah laku seksual, dan aspek-aspek kesehatan, kejiwaann dan kemasyarakatan. ${ }^{7}$

Profesor Gawshi ( dalam Yousef Madani) menyebutkan pendidikan seksual adalah untuk memberikan pengetahuan yang benar kepada anak yang menyiapkannya untuk beradaptasi secara baik dengan sikap-sikap seksual di masa depan kehidupannya; dan pemberian pengetahuan ini menyebabkan anak

5 Abdullah Nashih Ulwan, Pendidikan Anak dalam Islam (jilid 2), Terj. Jamaluddin Miri, Jakarta: Pustaka Amani, 2007), h. 1

6 Nuryani Rustaman, dkk, Ilmu dan Aplikasi Pendidikan, (Jakarta: Penerbit Intima, 2007), h. 297

${ }^{7}$ Sarlito Wirawan Sarwono, Psikologi Remaja, (Jakarta: Rajawali Pers, 2011) memperoleh kecenderungan logis yang benar terhadap masalah-masalah seksual dan reproduksi. ${ }^{8}$

Nina Surtiretna menyatakan bahwa pendidikan seks yaitu upaya memberikan pengetahuan tentang perubahan biologis, psikologis, dan psikososial sebagai akibat pertumbuhan dan perkembangan manusia. Pendidikan seks pada dasarnya merupakan upaya untuk memberikan pengetahuan tentang fungsi organ reproduksi dengan menanamkan moral, etika serta komitmen agama agar tidak terjadi penyalahgunaan organ reproduksi tersebut. $^{9}$

Pendidikan seks adalah membimbing serta mengasuh seseorang agar mengerti tentang arti, fungsi, dan tujuan seks sehingga ia dapat menyalurkan secara baik, benar dan legal. Pendidikan seks dapat dibedakan antara lain : 1). Sex Intruction, adalah penerangan mengenai anatomi seperti pertumbuhan rambut pada ketiak dan mengenai biologi dari reproduksi yaitu proses berkembangbiak melalui hubungan untuk mempertahankan jenisnya termasuk didalamnya pembinaan keluarga dan metode kontrasepsi dalam mencegah terjadinya kehamilan. 2). Education in sexsuality, meliputi bidang-bidang etika, moral, fisiologi, ekonomi dan pengetahuan lainnya yang dibutuhkan agar seseorang dapat memahami dirinya sendiri sebagai individual seksual serta mengadakan interpersonal yang baik.

Adapun perspektif Islam yang dimaksud dalam tulisan ini adalah pandangan Islam terhadap pendidikan seks. Islam adalah agama yang sempurna yang mengajarkan kepada kebaikan bagi seluruh umat manusia. Jadi disini Islam juga ikut berkontribusi dalam

8 Yousef Madani, Pendidikan Seks Usia Dini Bagi Nak Muslim,(Jakarta: Zahra Publishing House, 2014), Cetakan 1 , h. 122

9 Nina Surtiretna,.Remaja dan Problema seks Tinjauan Islam (Bandung: Remaja Rosdakarya, 2006), h. 2 
pendidikan seks, berupa memberikan bimbingan, aturan-aturan, dan batasan apa saja yang harus dilakukan dan tidak dilakukan dalam hal pendidikan seks.

Dari beberapa pengertian di atas dapat penulis simpulkan bahwa, yang dimaksud dengan pendidikan seks dalam pespektif Islam disini adalah suatu upaya untuk memberikan pengetahuan tentang perubahan-perubahan biologis pada manusia, alat-alat reproduksi dan fungsinya serta bagaimana cara untuk menjaga alat-alat reproduksi yang dimilikinya tersebut dengan menanamkan moral, etika serta komitmen agama Islam agar tidak terjadi penyalahgunaan organ reproduksi tersebut.

\section{PENDIDIKAN SEKS BERDASARKAN USIA PERKEMBANGAN}

Semakin transparannya berbagai informasi yang bisa diakses lewat jaringan internet oleh setiap orang sangat memungkinkan bagi sebagian besar anak dan remaja untuk memanfaatkannya sebagai media penolong dalam memenuhi rasa keingintahuannya mengenai seks. Padahal tidak semua informasi yang tersebar di internet merupakan informasi yang tepat untuk dikonsumsi anak dan remaja yang masih rentan karena tidak adanya filtrasi dari diri mereka sendiri untuk memilah informasi mana yang tepat.

Pendidikan seks merupakan upaya transfer pengetahuan dan nilai (knowledge and values) tentang fisik-genetik dan fungsinya khususnya yang terkait dengan jenis (sex) lakilaki dan perempuan sebagai kelanjutan dari kecenderungan primitif makhluk hewan dan manusia yang tertarik dan mencintai lain jenisnya. ${ }^{10}$

Pendidikan seks perlu dilakukan sejak usia dini dengan cara yang benar dan sesuai dengan tahapan perkembangan anak.

10 M. Roqib, Pendidikan seks pada anak usia dini, Jurnal Pemikiran Alternatif Pendidikan, 2008. 13(2), $1-12$.
Pendidikan seks untuk anak usia dini lebih kepada upaya pengajaran, penyadaran, dan penerangan tentang masalah-masalah seksual yang diberikan pada anak. Pengarahan dan pemahaman yang sehat tentang seks dari berbagai aspek, di mana selain menerangkan tentang aspek-aspek anatomi dan biologis juga menerangkan aspek-aspek psikologis dan moral. Anak yang secara naluriah memiliki rasa ingin tahu yang tinggi, lambat laun akan bertanya tentang bagian-bagian tubuhnya. Tidak mungkin, seorang anak tidak ingin mengetahui tentang beberapa organ vital tersebut sejak dini, padahal anak telah melalui proses-proses seksual tersebut secara alami.

Secara edukatif, anak dapat diberikan pendidikan seks sesuai dengan tahapan perkembangan yang telah ia capai. Pendidikan seks dapat diberikan sejak anak mulai bertanya tentang seks. Misalnya ketika bertanya tentang perbedaan alat kelaminnya dengan alat kelamin milik adik.

Untuk itu, sebaiknya diketahui dahulu bagaimana tahapan perkembangan anak secara keseluruhan untuk tiap usia anak. Berikut adalah cara memberikan pendidikan seksual pada anak sesuai dengan tahap perkembangannya : ${ }^{11}$

\section{Usia 2- 3 tahun}

Pada usia ini kosa kata anak mulai bertambah. Anak-anak mulai menirukan katakata yang ia dengar dari orang-orang di sekitarnya. Dia mulai memahami bahwa setiap wujud benda pasti memiliki 'nama/sebutan'. Orangtua sebaiknya mengenalkan alat kelamin pria dan wanita dengan nama yang sebenarnya, yakni 'penis' dan 'vagina', bukan dengan istilah-istilah lain. Hal ini dimaksudkan agar anak tidak bingung dan salah persepsi, dan

11 Natalia, M.Psi. Psikolog Anak dan Remaja (Psikolog Anak lulusan Magister Profesi Psikologi Klinis Anak UI). http://sayangianak.com/ini-caramemberikan-pendidikan-seksual-pada-anak-sesuaitahap-perkembangannya/ 
mengajarkan pada anak bahwa alat kelamin bukan untuk diejek atau dipermainkan.

\section{Usia 3-4 tahun}

Pada usia ini anak mulai bertanya “ Kok punya aku beda ama punya kakak?”, “ Kok bisa ada adik bayi?”. Berikan penjelasan dengan 'bahasa anak', bukan dengan bahasa yang rumit, misalnya : "Adik bayi itu dari dalam perut mama, awalnya kecil sekali lalu lama-lama menjadi besar dan siap untuk keluar ke dunia ini". Selain memberikan penjelasan bisa juga dengan menunjukkan contoh tantenya atau siapapun yang sedang mengandung anaknya, karena pada usia ini anak lebih mudah mencerna dengan melihat langsung.

\section{Usia 5-6 tahun}

Pada usia ini anak sudah mulai bisa diberikan penjelasan yang lebih kompleks misalnya dengan menyebutkan tentang bagian rahim seorang wanita. Penjelasan bisa dilakukan dengan menunjukkan sebuah gambar. Orangtua bisa mengatakan " Di dalam perut mama itu seperti ini keadaannya, ini namanya rabim, ini namanya indung telur, adik bayi nanti bobo di sini selama 9 bulan".

\section{Usia 6-7 tahun}

Pada usia ini kita mulai mengenalkan tentang hubungan antara laki-laki dan wanita, tentang konsep pernikahan, konsep keluarga, misalnya "Papa dan mama harus menikah dulu baru boleh punya adik bayi", mungkin bisa dikaitkan dengan konsep agama. Anak-anak juga selalu diingatkan untuk menjaga miliknya, misalnya : "Tidak boleh ada yang memegang kamu dari bagian leher ke bawah selain mama atau papa". Selain itu, tentang kebersihan juga harus selalu kita ingatkan.

\section{Usia 8-9 tahun}

Pada usia ini biasanya anak-anak sudah mulai mendengar tentang hal-hal seksual dari teman-temannya. Agar tetap terpantau, orangtua harus selalu menjaga kedekatan emosional dengan anak sehingga anak mau selalu terbuka. Katakan pada anak jika ingin mengetahui segala hal tentang seksual, anak bisa bertanya pada orangtuanya. Pada masa ini, orangtua sudah mulai harus menjelaskan dengan lebih detail tentang hubungan antara pria dan wanita, misalnya tentang bertemunya sel sperma dan sel telur, tentang penyakit seksual, tentang pelecehan seksual, dan lain sebagainya. Ajarkan bahwa kita harus selalu menjaga teman-teman kita dan tidak boleh mengejek fisik anak lain.

\section{Usia 9-11 tahun}

Pada usia ini anak mulai masuk ke masa pubertas. Perubahan pada tubuh mulai dirasakan oleh anak seperti tumbuh jakun, payudara, rambut, dan lainnya. Orangtua mulai bisa menjelaskan tentang menstruasi pada anak perempuan atau mimpi basah pada anak lakilaki. Setiap perubahan yang dirasakan oleh anak sebaiknya selalu didiskusikan bersama sehingga anak tidak mencari tahu dari media atau orang lain. Konsep pacaran juga sudah mulai diberikan pemahaman pada anak.

\section{$\underline{\text { Usia } 12 \text { tahun ke atas }}$}

Pada usia ini anak sudah mulai paham tentang interaksi antara lawan jenis dan ada beberapa dari anak-anak yang sudah mulai berpacaran. Tentunya kontrol orangtua harus semakin ketat. Orangtua harus selalu mengingatkan bahwa "tidak boleh menyentuh bagian tubuh orang lain", "harus menghargai orang lain", "tidak boleh memaksa", dan lain sebagainya. Lakukan pendekatan pada anak dengan lembut, tanpa kekerasan, karena semakin kita keras pada anak, mereka akan semakin membangkang dan akan sengaja melakukan hal-hal yang dilarang.

Keterlibatan aktif orangtua dalam pendidikan seks membuat anak menguasai lebih banyak pengetahuan mengenai 
terminologi genital yang sesuai jika dibandingkan dengan pendidikan seks yang diajarkan oleh guru. Anak yang dilatih oleh orangtuanya juga akan menerima pengetahuan yang berulang-ulang secara konsisten dalam lingkungan yang natural atau alamiah. Hal ini semakin menegaskan bahwa orangtua merupakan orang dewasa pertama yang dijumpai dan sebagai pendidik utama anak.

\section{PENDIDIKAN SEKS DALAM PERSPEKTIF ISLAM}

Omar Mohammad Al Toumy Al Syabany dalam bukunya tentang falsafah pendidikan Islam, manusia memiliki dorongan untuk mencari minuman, makan, pakaian, perlindungan, seks, keibuan, kebapakan, dan kecenderungan untuk menguasai demi kelangsungan hidup, kecedenderungan untuk istirahat, tidur dan berpindah. ${ }^{12}$

Munculnya isu pendidikan seks menjadikan polemik tersendiri dalam berbagai bidang dan tentunya memunculkan realitas dan fenomena yang cukup penting di masyarakat. Beberapa kalangan menilai bahwa pendidikan seks adalah sesuatu yang tabu dan tidak perlu untuk diajarkan kepada anak-anak, karena ini adalah sesuatu yang instingtif. Beberapa pihak lain berpendapat bahwa pendidikan seks adalah pengetahuan yang perlu untuk diketahui oleh anak-anak sebagai modal untuk menghadapi usia remaja dan usia pubertas.

Agama Islam merupakan agama untuk seluruh umat manusia sampai akhir zaman maka Islam mengatur dan memberi arahan kepada umat manusia di dalam hukum Islam atau fiqih. Fiqih mencakup segala aspek kehidupan manusia dalam memenuhi segala permasalahan dalam hidupnya termasuk didalamnya membahas masalah-masalah yang mencakup kehidupan seks. Oleh karena itu, Agama Islam juga ikut berkontribusi dalam

12 Omar Mohammad Al Toumy Al Syabany, Falsafah Pendidikan Islam, (Jakarta: Bulan Bintang, 1979), h. 142 masalah ini, guna menanggulangi problem yang dihadapi remaja saat menginjak masa baligh serta memberikan perlindungan bagi remaja dari segala gejala-gejala negatif yang mungkin timbul.

Mursy dalam bukunya Bayyinatul Muchtaromah menjelaskan bahwa pendidikan seks menurut Islam adalah upaya pengajaran dan penerapan tentang masalah-masalah seksual yang diberikan pada anak, dalam usaha menjaga anak dari kebiasaan yang tidak Islami serta menutup segala kemungkinan kearah hubungan seksualitas yang terlarang (perzinaan). ${ }^{13}$

Urgensi dari pendidikan seks kepada anak adalah dengan menanamkan nilai-nilai agama yang kuat untuk membentuk karakter anak agar ketika dewasa nanti anak memiliki bekal yang kuat dalam dirinya untuk tidak terjerumus dalam pergaulan seks bebas. Nilai agama sangat berperan penting sebagai dasar pemahaman anak untuk dapat menjaga dirinya dengan baik.

Tidak disangsikan lagi bahwa Islam tidak sekedar menganjurkan perbaikan perilaku seksual pada dunia anak-anak, melainkan juga (dan ini palin utama) dalam kehidupan orang dewasa. Sebab jika seorang pendidik muslim berhasil dalam menata kegiatan seksual pada orang dewasa, hal itu akan berpengaruh terhadap pendidikan seksual pada anak, dimana orang dewasa, secara khusus orang tua, mengajarkan kepada anak sikap-sikap seksual yang aman atau sehat. ${ }^{14}$

Pendidikan seks sebagai bagian dari sebuah aktifitas pendidikan harus memiliki tujuan yang jelas, sehingga pendidikan seks yang diberikan mampu memberikan pengetahuan yang benar kepada anak. beberapa tujuan pendidikan seks:

13 Bayyinatul Muchtaromah, Pendidikan Reproduksi bagi Anak Menuju Aqil Baligh. (Malang: UIN Malang Press, 2008), h. 9

${ }^{14}$ Yusuf Madan, Sex Education For Children (Panduan Islam Orang Tua dalam Pendidikan Seks untuk. Anak).

(Bandung : Hikmah PT Mizan Publika, 2004), h. 184 
1. Memberikan pemahaman dengan benar tentang materi pendidikan seks diantaranya memahami organ reproduksi, identifikasi dewasa/baligh, kesehatan seksual, penyimpangan seks, kehamilan, persalinan, nifas, bersuci dan perkawinan.

2. Menepis pandangan miring khalayak umum tentang pendidikan seks yang dianggap tabu, tidak islami, seronok, nonetis dan sebagainya.

3. Pemahaman terhadap materi pendidikan seks pada dasarnya memahami ajaran Islam.

4. Pemberian materi pendidikan seks disesuaikan dengan usia anak yang dapat menempatkan umpan dan papan.

5. Mampu mengantisipasi dampak buruk akibat penyimpangan seks.

6. Menjadi generasi yang sehat. ${ }^{15}$

Tujuan pendidikan seks dalam Islam adalah untuk menjaga keselamatan dan kehormatan serta kesucian anak-anak kita di tengah-tengah masyarakat. Pendidikan seks diadakan adalah untuk membantu anak agar dapat bertanggung jawab atas penggunaan alat kelaminnya, dan mampu menjaga dirinya dari pelanggran-pelanggaran seksual. $^{16} \quad$ Dalam Islam, pendidikan seks juga diberikan kepada umat manusia, agar mereka tidak terperosok ke dalam jurang kenistaan, yakni perzinahan.

Dalam surat Al-Isra(17): 32:

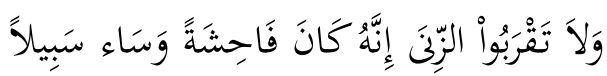

Dan janganlah kamu mendekati rina; sesungguhnya zina itu adalah suatu perbuatan yang keji dan suatu jalan yang buruk.

Berdasarkan Alquran di atas, maka pendidikan seks tidaklah tabu sebagaimana anggapan sebagian masyarakat. Pendidikan sangatlah perlu diberikan karena hubungannya dengan akhlak dan syariat Islam. Oleh karena itu, kehidupan seks perlu dibimbing dengan

15 Moh. Rasyid, Pendidikan Seks, Mengubah Seks Abnormal Menuju Seks yang Lebih Bermoral, (Semarang: Dwitama Asrimedia, 2013) h. 84-85

16 Sayyid Muhammad Ridho, Perkawinan dan Seks, (Jakarta: Lentera, 1996), h. 15 cara langsung. Membimbing kehidupan seks manusia itu wajar, sopan, dan benar sesuai dengan syariat Islam.

Islam membicarakan pendidikan seks sebagai bagian integral dari pendidikan aqidah, ibadah, dan akhlak. Terlepasnya pendidikan Islam dari ketiga unsur tersebut akan menyebabkan ranncunya pendidikan seks itu seniri, bahkan mungkin menimbulkan kesesatan dan penyimpangan dari tujuan asal manusia melakukan kegiatan seksual dalam rangka pengabdian kepada Allah. Allah SWT menggambarkan institusi perkawinan sebagai sebuah institusi yang suci yang mampu memberikan ketenangan dan kasih sayang, yang merupakan salah satu jalan bagi manusia dalam mengabdi kepada Allah, sebagaimana dituliskan dalam Al Qur'an surat Ar-Rum(30) : 21:

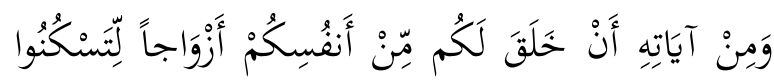

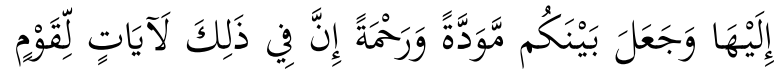
يَتَفَكَرُونَ

Dan di antara tanda-tanda kekuasaan-Nya ialah Dia menciptakan untukemu isteri-isteri dari jenismu sendiri, supaya kamu cenderung dan merasa tenteram kepadanya, dan dijadikan-Nya di antaramu rasa kasib dan sayang. Sesunggubnya pada yang demikian itu benar-benar terdapat tanda-tanda bagi kaum yang berfikir.

Dari ayat di atas dijelaskan bahwa Islam mengharamkan upaya menghindarkan diri dari perkawinan dan zuhud dengan niat mengosongkan diri untuk beribadah dan mendekatkan diri kepada Allah. Terutama sekali jika ia telah mampu untuk biaya kawin dan segala sarananya mudah ia dapatkan. ${ }^{17}$ Islam memberikan jalan agar manusia terhindar dari perilaku seks yang terlarang dengan pernikahan.

Pola pendidikan seks dalam Islam yang praktis diberikan orang tua kepada anaknya tidaklah melalui metode pembahasan lisan

${ }^{17}$ Abdullah Nashih Ulwan, Op. Cit, h. 76 
yang menghilangkan rasa malu manusia. Metode pendidikan kenabian yang sejalan dengan fitrah manusia yang malu mebicarakan hal-hal yang seronok, karena berdampak menggusur secara bertahap kepekaan terhadap nilai-nilai akhlak yang luhur. Ini berbeda dengan metode barat yang penuh dengan muatan seronok dalam pendidikan seksual, karena rangsangan seksual itu tidak memerlukan pembicaraan namun timbul karena terlihatnya bagian-bagian yang merangsang dari lawan jenisnya. Karena itulah Islam melakukan pencegahan sedini mungkin agar rangsangan yang bersifat naluriah itu tidak mengakibatkan bahaya bagi anakanak.

Cara-cara pengajaran pendidikan seksual Islam yang diajarkan Rasulullah antara lain:

1. Pemisahan tempat tidur. Rasulullah SAW bersabda, "Surublab anak-anakmu shalat ketika mereka berumur tujuh tabun, dan pukullah mereka (tanpa menyakitkan jika tidak mau shalat) ketika berumur sepulub tabun; dan pisabkanlah tempat tidur mereka." (HR. Abu dawnd). Perintah Rasulullah SAW untuk melakukan pemisahan tempat tidur ini secara praktis membangkitkan kesadaran pada anak-anak tentang status perbedaan kelamin. Cara semacam ini disamping memelihara nilai akhlak sekaligus mendidik anak mengetahui batas pergaulan antara laki-laki dan perempuan.

2. Mengenalkan batasan aurat dan menerapkannya dalam kehidupan seharihari. Kata "aurat" bersal dari bahasa Arab, artinya yang tercela kalau tampak. Bila bagian tertentu dari tubuh manusia terbuka dan terlihat orang lain, maka yang bersangkutan merasa malu.

Masalah batasan aurat merupakan ketentuan agama yang tidak dapat direkayasa oleh ide dan gagasan manusia sendiri, apalagi manusia yang tidak mengenal tanggung jawab kehidupan akhirat.

Batasan aurat wanita adalah seluruh badan kecuali muka dan telapak tangan, sedangkan batasan aurat laki-laki adalah batas antara lutut sampai pusar. Orang tua berkewajiban menyuruh anak-anak putrinya untuk menurut auratnya, sebagaimana firman Allah dalam surat Al-Ahzab (33): 59:

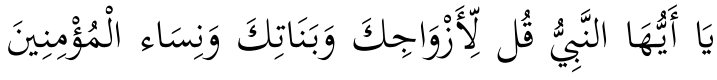

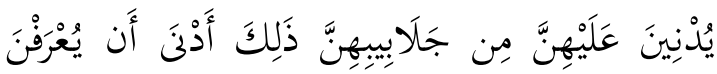

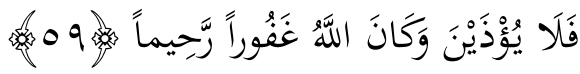

Hai Nabi katakanlab kepada isteri-isterimu, anak-anak perempuanmu dan isteri-isteri orang mu'min: "Hendaklab mereka mengulurkan jilbabnya ke selurub tubub mereka". Yang demikian itu supaya mereka lebih mudah untuk dikenal, karena itu mereka tidak diganggu. Dan Allah adalab Maha pengampun lagi Maha penyayang.

Janganlah anak-anak yang telah baligh dibiarkan berpakaian sesuka hati, berpakaian dengan dada terlihat, leher terbuka, dan terlihat pahanya.

3. Mengajarkan mereka meminta izin ketika memasuki kamar orang tuanya terutama dalam tiga waktu, sesuai dengan firman Allah dalam surat An-Nur (24): 58-59:

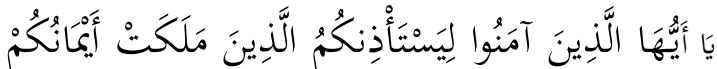

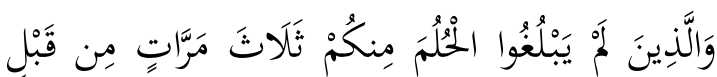

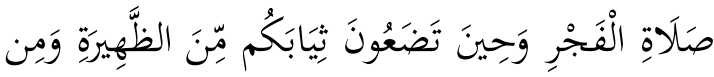

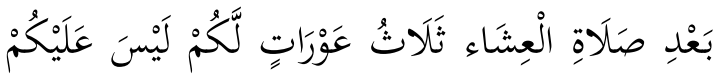

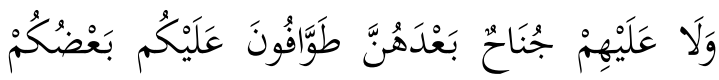

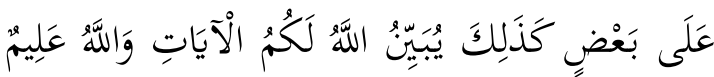
حَكِيمُ

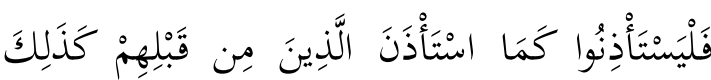

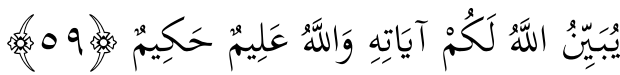
Hai orang-orang yang beriman, hendaklab budakbudak. (lelaki dan wanita) yang kamu miliki, dan orang-orang yang belum balig di antara kamu, 
meminta iz̧in kepada kamu tiga kali (dalam satu hari) yaitu: sebelum sembabyang subub, ketika kamu menanggalkan pakaian (luar) mu di tengah bari dan sesudah sembahyang Isya'. (Itulah) tiga aurat bagi kamu. Tidak ada dosa atasmu dan tidak (pula) atas mereka selain dari (tiga waktu) itu. Mereka melayani kamu, sebahagian kamu (ada keperluan) kepada sebahagian (yang lain). Demikianlah Allah menjelaskan ayat-ayat bagi kamu. Dan Allab Maha Mengetabui lagi Maha Bijaksan (58). Dan apabila anak-anakmu telah sampai umur balig, maka bendaklah mereka meminta izin, seperti orang-orang yang sebelum mereka meminta irin. Demikianlah Allah menjelaskan ayat-ayat-Nya. Dan Allah Maha Mengetabui lagi Maha Bijaksana (59).

\section{KESIMPULAN}

Pendidikan seks dalam pespektif Islam disini adalah suatu upaya untuk memberikan pengetahuan tentang perubahan-perubahan biologis pada manusia, alat-alat reproduksi dan fungsinya serta bagaimana cara untuk menjaga alat-alat reproduksi yang dimilikinya tersebut dengan menanamkan moral, etika serta komitmen agama Islam agar tidak terjadi penyalahgunaan organ reproduksi tersebut.

Secara edukatif, anak dapat diberikan pendidikan seks sesuai dengan tahapan perkembangan yang telah ia capai. Pendidikan seks dapat diberikan sejak anak mulai bertanya tentang seks.

Tujuan pendidikan seks dalam Islam adalah untuk menjaga keselamatan dan kehormatan serta kesucian anak-anak kita di tengah-tengah masyarakat. Pendidikan seks diadakan adalah untuk membantu anak agar dapat bertanggung jawab atas penggunaan alat kelaminnya, dan mampu menjaga dirinya dari pelanggran-pelanggaran seksual. Pendidikan seks juga diberikan kepada umat manusia, agar mereka tidak terperosok ke dalam jurang kenistaan, yakni perzinahan.

Di antara cara-cara memberikan pendidikan seks menurut Islam sebagaimana yang diajarkan Rasulullah SAW adalah: a. Pemisahan tempat tidur; b. Mengenalkan batasan aurat dan menerapkannya dalam kehidupan sehari-hari; c. Mengajarkan mereka meminta izin ketika memasuki kamar orang tuanya terutama dalam tiga waktu. 


\section{DAFTAR KEPUSTAKAAN}

Langulung, Hasan, Asas-asas Pendidikan Islam, Jakarta: Pustaka al-Husna, 1988

Madani, Yousef , Pendidikan Seks Usia Dini Bagi Nak Muslim, Jakarta: Zahra Publishing House, 2014, Cetakan 1

Muchtaromah, Bayyinatul, Pendidikan Reproduksi bagi Anak Menuju Aqil Baligh. Malang: UIN Malang Press, 2008

Rahman, Rini, Nilai-nilai Pendidikan dalam Karya Sastra Hamka dan Transformasinya dalam Pembelajaran di Sekolah, Jakarta: Prasasti, 2015

Rasyid, Moh., Pendidikan Seks, Mengubah Seks Abnormal Menuju Seks yang Lebib Bermoral, Semarang: Dwitama Asrimedia, 2013

Ridho, Sayyid Muhammad, Perkawinan dan Seks, Jakarta: Lentera, 1996

Roqib, M.. Pendidikan seks pada anak usia dini, Jurnal Pemikiran Alternatif Pendidikan, 2008,13(2), 1-12.

Rustaman, Nuryani, dkk, Ilmu dan Aplikasi Pendidikan, Jakarta: Penerbit Intima, 2007

Sarwono, Sarlito Wirawan, Psikologi Remaja, Jakarta: Rajawali Pers, 2011

Surtiretna, Nina,.Remaja dan Problema seks Tinjauan Islam Bandung: Remaja Rosdakarya, 2006

Al Syabany, Omar Mohammad Al Toumy, Falsafah Pendidikan Islam, Jakarta: Bulan Bintang, 1979

Syafrudin, Ayip, Islam dan Pendidikan Seks Anak, Solo: Pustaka Manfiq,1991

Ulwan,Abdullah Nashih, dan Hasan Hathout. Pendidikan Seks, Bandung: Remaja Rosydakarya, 1992

Ulwan, Abdullah Nashih, Pendidikan Anak dalam Islam (jilid 2), Terj. Jamaluddin Miri, Jakarta: Pustaka Amani, 2007

Madan, Yusuf Madan, Sex Education For Children (Panduan Islam Orang Tua dalam Pendidikan Seks untuk, Anak). (Bandung : Hikmah PT Mizan Publika, 2004

http:/ / sayangianak.com/ini-cara-memberikan-pendidikan-seksual-pada-anak-sesuai-tahapperkembangannya/ 